\title{
Quality System Certifications in Education Sector
}

\author{
Rajyashree Yadav \\ Associate Professor \\ Government R.D. Girls College \\ Bharatpur, India
}

\author{
Neeraj Yadav* \\ Director \\ Qualicon Consultancy Co. \\ India \\ *QualiconConsultancy@ hotmail.com
}

\author{
Jaishree Yadav \\ Freelancing Education Consultant \\ India
}

\begin{abstract}
Different quality system certifications, accreditations, and awards are available for education sector. The paper compares some of these choices so that educational institutes can decide which option suits them more. Literature review and expert opinion of three experts are used for this purpose. Strategies to make these certifications more popular among users are also suggested.
\end{abstract}

Keywords-ISO 9001, ISO 21001, quality certification and accreditation, Malcolm Baldrige National Quality Award, EFQM model

\section{INTRODUCTION}

Different quality system certifications, accreditations, and awards are available for education sector [1-3]. Some of these are applicable only at national level whereas, some are available on international platforms. Popular and commonly used certifications in education field are discussed in this paper. Their comparison from different perspectives is also provided. Strategies to make these certifications more popular among users are suggested as well.

International Organization for Standardization (ISO) [4] is a pioneer organization in developing standards. It publishes several standards for products, processes, and systems. The 'ISO' acronym is derived from Greek word 'isos' meaning equal [5]. These standards are universally applicable and are equally recognized throughout the world.

Many standards are developed by ISO for quality management systems also. Some of these are generic standards i.e. can be applied in any organization, of any size or business segment. One such standard is ISO 9001 [6]. On the other hand, some standards are sector specific and apply only in that specific segment e.g. ISO 21001 [7] which is a quality management system standard for education sector.

All ISO standards undergo periodic revisions. In year 2015, ISO revised many standards including ISO 9001, ISO 14001 [8] etc. A new high-level structure [9] was proposed in this round of revisions under which all management system standards have uniform requirement structure. The requirements however changes from standard to standard. A review of some relevant standards is provided in following section.

\section{LITERATURE REVIEW}

\section{A. ISO 9001 Quality Management System [4]}

ISO 9001 is one of the most popular management system series for quality management. As per 2019 survey of ISO [10], over $8,83,521$ certificates have been released for ISO 9001 system worldwide. First released in 1987, the standard has been revised in 1994, 2000, 2008, and 2015. In fact, it is a series of standards comprising of many documents. The ISO 9000 covers definitions and vocabulary, ISO 9004 provides guidelines for improvement, ISO 19011 provides guidelines for auditing, ISO 9001 is the certification standard and contains requirements for quality management system certification. The requirements of ISO 9001:2015 are specified in seven clauses numbered from 4 to 10 as specified in Table-1. The structure of requirements is built on famous P-D-C-A (Plan-Do-Check-Act) improvement cycle.

This standard is open for every type of organization including education sector. Each organization has to tailor its management system according to the requirements specified in this standard and has to demonstrate continual improvement in performance over time. The impact of ISO 9001 on performance of educational institutes is well established $[11,12]$.

\section{B. ISO 21001 Management System for Educational Organizations [7]}

In contrast with generic quality management system ISO 9001, this standard is tailored specifically for educational organizations. The structure of this standard is very similar to ISO 9001:2015. This standard also has same principal clauses 
as ISO 9001:2015 however, the content and sub-clauses differ. The major changes from ISO 9001:2015 standard are highlighted in Table-1. Since this is a new standard it has not become so popular so far. The 2019 survey of ISO [10] did not include this standard and therefore no information is authentically available on exact number of certifications issued against this standard in different countries, and worldwide.

Many annexures are provided in this standard to relate it with other relevant standards. Annex F illustrates how to map this document to other regional standards in the field of education. An example of mapping the requirements to European Quality Assurance Framework for Vocational Education and Training (EQAVET) is provided in the standard. On similar pattern, organizations from any country can map these requirements with their country's education system certification/accreditation requirements, if any. In India, National Assessment and Accreditation Council (NAAC) provides this accreditation.

TABLE I. COMPARISON OF ISO 9001:2015 AND ISO 21001:2018 REQUIREMENTS

\begin{tabular}{|c|c|c|}
\hline ISO 9001:2015 Requirements & Additional/Specific/Different Requirements in ISO 21001:2018 & $\begin{array}{l}\text { Phase of P- } \\
\text { D-C-A Cycle }\end{array}$ \\
\hline 0 Introduction & $\begin{array}{l}\text { Principles of EOMS. EOMS Framework } \\
\text { Vision, Mission, and Strategies }\end{array}$ & - \\
\hline 1 Scope & - & - \\
\hline 2 Normative Reference & - & - \\
\hline 3 Terms and Definitions & Education sector specific definitions & - \\
\hline 4 Context of Organization & Management system for educational organizations & \multirow{3}{*}{ Plan } \\
\hline 5 Leadership & Focus on learners and other beneficiaries & \\
\hline 6 Planning & - & \\
\hline 7 Support & Additional requirements for special needs education & \multirow[b]{2}{*}{ Do } \\
\hline 8 Operations & $\begin{array}{l}\text { Additional requirements for special needs education } \\
\text { Protection and transparency of learner's data }\end{array}$ & \\
\hline 9 Performance Evaluation & Satisfaction of learners, other beneficiaries, and staff. & Check \\
\hline 10 Improvement & - & Act \\
\hline $\begin{array}{l}\text { Annex A: Clarification of new structure, } \\
\text { terminology, and concepts. } \\
\text { Annex B: Other International Standards on } \\
\text { quality management and quality } \\
\text { management systems developed by } \\
\text { ISO/TC } 176\end{array}$ & $\begin{array}{l}\text { Annex A: Additional requirements for early childhood education } \\
\text { Annex B: Principles for an EOMS } \\
\text { Annex C: Classification of interested parties in educational } \\
\text { organizations } \\
\text { Annex D: Guidelines for communication with interested parties } \\
\text { Annex E: Processes, measures, and tools in educational organizations } \\
\text { Annex F: Example of mapping to regional standards } \\
\text { Annex G: Health and safety considerations for educational organizations }\end{array}$ & Annexures \\
\hline
\end{tabular}

\section{NAAC (India): National Assessment and Accreditation Council [13]}

In India, an autonomous body National Assessment and Accreditation Council (NAAC), does accreditation of higher education institutions and provides them grading on the basis of seven performance criteria [14] stipulated in Table-2. The accreditation of schools, i.e. elementary education institutes, is done by National Accreditation Board for Education and Training (NABET) [15].

TABLE II. NAAC CRITERIA

\begin{tabular}{|l|l|l|}
\hline \multicolumn{1}{|c|}{$\begin{array}{c}\text { Curricular } \\
\text { Aspects }\end{array}$} & $\begin{array}{c}\text { Teaching, Learning, } \\
\text { and Evaluation }\end{array}$ & $\begin{array}{c}\text { Research, } \\
\text { Innovations, and } \\
\text { Extension }\end{array}$ \\
\hline $\begin{array}{l}\text { Infrastructure and } \\
\text { Learning Resources }\end{array}$ & $\begin{array}{l}\text { Student Support and } \\
\text { Progression }\end{array}$ & $\begin{array}{l}\text { Governance, } \\
\text { Leadership, and } \\
\text { Management }\end{array}$ \\
\hline $\begin{array}{l}\text { Institutional Values } \\
\text { and Best Practices }\end{array}$ & & \\
\hline
\end{tabular}

\section{TQM Models / Education Excellence Frameworks}

While ISO standards, NAAC, NABET etc. prescribe minimum requirements to achieve certification or grading, TQM models and Excellence Frameworks aim for best-in-class performance. Using these excellence-frameworks, organizations can benchmark their performance against best performing organization. These frameworks carry point-based scoring system and every organization is assigned a score based on their performance in comparison with other entities. The highest scoring organizations are then awarded on annual basis. One such framework is Malcolm Baldrige National Quality Award [16] which is applicable for US based organizations. The model however, can be used anywhere in the world to achieve excellence. The award is offered to six types of organizations including Manufacturing, Services, Small Business, Healthcare, Non-profit, and Educational entities. The 7 performance evaluation criteria for Education sector are mentioned in Table-3. A similar framework for organizational change and performance improvement is EFQM Model [17]. The model is globally applicable and its evaluation categories are also mentioned in Table-3. Blackmore and Douglas [18] summarized benefits of EFQM model in educational institutes, whereas, Lee et al. [19] provided details about impact of Malcolm Baldridge framework. 
TABLE III. TQM / BUSINESS EXCELLENCE MODELS - EVALUATION CATEGORIES

\begin{tabular}{|l|l|}
\hline $\begin{array}{c}\text { Baldrige Excellence } \\
\text { Framework - } \\
\text { Educational Institutions }\end{array}$ & \multicolumn{1}{|c|}{ EFQM Model (Common for All) } \\
\hline Leadership & Organization \\
\hline Strategy & $\begin{array}{l}\text { Direction - Purpose, Vision, Strategy, } \\
\text { Organizational Culture and Leadership }\end{array}$ \\
\hline $\begin{array}{l}\text { Measurement, Analysis, } \\
\text { and Knowledge } \\
\text { Management }\end{array}$ & $\begin{array}{l}\text { Execution - Engaging Stakeholders, } \\
\text { Creating Sustainable Value, Driving } \\
\text { Performance and Transformation }\end{array}$ \\
\hline Workforce & $\begin{array}{l}\text { Results-Stakeholder Perceptions, Strategic } \\
\text { and Operational Performance }\end{array}$ \\
\hline Operations & \\
\hline Customers & \\
\hline Results & \\
\hline
\end{tabular}

\section{Challenges FaCed And Methodology Adopted}

Since there are many certification and accreditation options available, it is a challenging task for educational organizations to decide which option they shall adopt. To facilitate this task, a team of 3 experts with relevant experience was constituted in this study and their opinion in the form of relative ratings is captured for each of the certification choices. The team details are described in Table-4.

TABLE IV. EXPERT TEAM STRUCTURE

\begin{tabular}{|l|l|l|}
\hline S. No. & Experience & \multicolumn{1}{|c|}{ Area of Expertise } \\
\hline 1 & 23 Years & $\begin{array}{l}\text { Consultant, Trainer, and Lead Auditor of } \\
\text { different ISO standards Implemented } \\
\text { various ISO standards in more than 500 } \\
\text { organizations. }\end{array}$ \\
\hline 2 & 27 Years & $\begin{array}{l}\text { Associate Professor in Government } \\
\text { Educational Institute offering Graduate and } \\
\text { Post Graduate Study Programs }\end{array}$ \\
\hline 3 & 25 Years & Principal of Teacher's Education Institute \\
\hline
\end{tabular}

\section{RESULTS AND DISCUSSION}

The cost of ISO 9001 certification is least among all these options because it is one of the most common certifications. Many certification agencies and consultancy enterprises offer services for this certification. ISO 21001 is also a standard of ISO family but ha not yet gained popularity. Therefore, the agencies offering this certification are limited and they charge a premium for this service. The cost of TQM/excellence awards is comparatively very high. The time required, and ease of fulfilling their requirements are also tremendous.

In terms of recognition, local recognition is higher for NAAC accreditation because it is used for local ranking and admission process. However, it has low international recognition. Excellence awards are widely recognized globally. ISO standards are also popular worldwide. Government support in terms of grants and subsidies is available for ISO 9001 and NAAC accreditation in India.

Considering both tangible and intangible gains, the returnon-investment is very high for Excellence awards, and includes global recognition, high stakeholder satisfaction, preference by students in admission etc. The same logic can be extended to other decision aspects i.e. Performance Improvement, Stakeholder Satisfaction, Prestige, and Effort Involved as shown in Table-5.

Since business excellence awards/frameworks are so well recognized and beneficial, they are most difficult to get. Moreover, the award is given to only one or few best performing organizations and not to every participating organization. ISO and NAAC/NABET are relatively easy and are awarded to every organization that fulfils the requirements.

It is also noteworthy that ISO certification is not a one-time process, it requires periodic assessment to ensure continued compliance. Awards are, in contrast, usually a one-time affair. Although there is no official restriction on re-participation, it rarely happens. Usually, all these certifications are voluntary, sometimes NAAC accreditation is mandatory in India to offer certain courses.

TABLE V. COMPARISON OF VARIOUS CERTIFICATION/ACCREDITATION SCHEMES

\begin{tabular}{|c|c|c|c|c|}
\hline Decision Aspect & ISO 9001:2015 & ISO 21001:2018 & $\begin{array}{l}\text { NAAC / } \\
\text { NABET }\end{array}$ & $\begin{array}{c}\text { Malcolm Baldrige / } \\
\text { EFQM }\end{array}$ \\
\hline Cost & Low & Medium & High & Very High \\
\hline Time Required to Achieve Certification & Minimum & Minimum & Moderate & Maximum \\
\hline Ease of Fulfilment of Requirements & Easy & Easy & Moderate & Tough \\
\hline Recognition at National Level & Moderate & Moderate & Maximum & Limited \\
\hline Recognition at Global Level & Moderate & Moderate & Limited & Maximum \\
\hline Government Financial Aid Options & Few & None & Few & None \\
\hline Return on Investment & High & High & High & Very High \\
\hline Chances of Achieving Certification / Award & High & High & High & Very Low \\
\hline Performance Improvement & Significant & Significant & High & Highest \\
\hline Stakeholder Satisfaction & Significant & Significant & High & Highest \\
\hline Prestige & Significant & Significant & High & Highest \\
\hline Effort Involved & Significant & Significant & High & Highest \\
\hline Offered By: Single or Multi Agencies & Multiple & Multiple & Single & Single \\
\hline One-time/Periodic & Periodic & Periodic & Less Frequent & Usually One Time \\
\hline Legal/Statutory Binding & No & No & Sometimes & No \\
\hline
\end{tabular}




\section{CONCLUSION AND IMPLICATIONS}

As mentioned before, that ISO 9001 and ISO 21001 are not very popular in education sector, new strategies are needed to increase their penetration and making them a preferred choice.

One possible way is to increase awareness about these standards in general public. Currently, individuals while taking admission to educational institutes do not demand these certifications, although these are developed primarily for their satisfaction. Quality standards in other sectors e.g. manufacturing get a huge drive from customers because they insist on having ISO certification to initiate business dealing. Many quality system standards cover entire supply chain under certification scheme. IATF 16949 [20] is a famous quality standard that focusses on automotive supply chains. This focus helps it in wider recognition and deep penetration in automotive organizations. ISO 21001 also has to adopt a similar approach.

Another possible improvement domain is linking these certifications to educational institute rankings. No educational ranking providers e.g. Times higher education ranking [21] or QS world university rankings [22] use certification as one of their ranking criteria. If these certifications get linked to these rankings, they will automatically become a sought-after affair. In addition, the performance data of educational institutes analysed on standard requirements of ISO 9001 or ISO 21001, will be available for these ranking agencies. The ranking agencies can use these data in their reports to make them more data oriented and reduce dependence on perception based ranking factors.

\section{REFERENCES}

[1] N. Cömert, I. Akgun, D. Karaköy, and P. Kaya, "Quality Management Approaches and their Comparison in Higher Education: Marmara University Faculty of Business Administration Quality Studies," The Online Journal of Quality in Higher Education, vol. 6, no. 3, pp. 101$111,2019$.
[2] I. Heras-Saizarbitoria, M. Casadesús, and F. Marimón, "The impact of ISO 9001 standard and the EFQM model: The view of the assessors," Total Quality Management and Business Excellence, vol. 22, no. (2), pp. 197-218, 2011.

[3] C. Singh and K. Sareen, "Effectiveness of ISO 9000 standards in Indian educational institutions: a survey," International Journal of Services Technology and Management, vol. 7, no. (4), pp. 403-415, 2006.

[4] https://www.iso.org/about-us.html

[5] S. Dowlatshahi and C. Urias, "An empirical study of ISO certification in the maquiladora industry," International Journal of Production Economics, vol. 88, no. 3, pp. 291-306, 2004.

[6] https://www.iso.org/iso-9001-quality-management.html

[7] https://www.iso.org/standard/66266.html

[8] https://www.iso.org/standard/60857.html

[9] https://www.iso.org/management-system-standards.html

[10] https://www.iso.org/the-iso-survey.html

[11] A. Jorge Gamboa and N. Filipe Melão, "The impacts and success factors of ISO 9001 in education: Experiences from Portuguese vocational schools," International Journal of Quality \& Reliability Management, vol. 29, no. 4, pp. 384-401, 2012.

[12] R. Ab Wahid, "Sustaining ISO 9001-based QMS in higher education: a reality?," The TQM Journal, vol. 31, no. 4, pp. 563-577, 2019.

[13] http://www.naac.gov.in/

[14] http://naac.gov.in/index.php/assessment-accreditation\#accreditation

[15] https://nabet.qci.org.in/flip book/mobile/index.html

[16] https://www.nist.gov/baldrige/publications/baldrige-excellenceframework

[17] https://www.efqm.org/index.php/efqm-model/

[18] J. Blackmore and A. Douglas, "Towards a "better" University: the Use of the EFQM Model in a UK Higher Education Institution," Asian Journal on Quality, vol. 4, no. 2, pp. 1-15, 2003.

[19] S.F. Lee, K.K. Lo, R.F. Leung, and A. Sai On Ko, "Strategy formulation framework for vocational education: integrating SWOT analysis, balanced scorecard, QFD methodology and MBNQA education criteria," Managerial Auditing Journal, vol. 15, no. 8, pp. 407-423, 2000.

[20] https://www.iatfglobaloversight.org

[21] https://www.timeshighereducation.com/world-university-rankings

[22] https://www.topuniversities.com/university-rankings/world-universityrankings/2021 